\title{
EU's rolle i en ny verdensorden
}

\section{Jørgen Ørstrøm Møller}

\section{Danmark overtager formandskabet i EU på et tids- punkt, hvor danskerne ikke kan finde ud af deres tilknytning til Europa, og EU står rådvild over for sin plads i det geopolitiske billede. Det ser svært ud; og det bliver det også - for Danmark og for EU}

På sin vis har Europa gode kort på hånden. Eurozonen tegner sig for 14,6 pct. (EU næsten 20 pct.) af det globale bruttonationalprodukt (BNP). EU er verdens største handelspartner, stærk inden for nøglesektorer som mekanik, bilindustri, flyindustri, rumfart, kemisk industri og farmaceutika for blot at nævne et par områder. I et vist omfang er det fortsat EU, som evner at føre an på vigtige holdningsmæssige globale områder som fx klima, selv om vi nok ikke står helt så godt, som vi selv tror. I Europas nærområde spiller EU en meget vigtig rolle, som det er set i Libyen, i Kaukasus og Ukraine.

Der mangler visionen om hvilket Europa, der skal stemme op for malstrømmen, og hvilken rolle, der skal spilles i verden. Europa og USA stod i mange årtier sammen om fælles værdier. Nu glider de gradvist fra hinanden med et USA, der ser mere mod Stillehavet end mod Atlanten og betegner Europa som 'det gamle' kontinent med tidligere forsvarminister Donald Rumsfelds ord.

I foråret 2011 umiddelbart forud for sin afgang fortalte forsvarsminister Robert Gates europæerne, at i store træk måtte de fremover klare problemerne selv. Tidsmæssigt faldt det næsten sammen med aktionen $\mathrm{i}$ Libyen, hvor USA valgte at spille en tilbagetrukken rolle, der gav anledning til den formulering, som synes at karakterisere USA under præsident Barack Obama 'the president is leading from behind'. I lyset af den transatlantiske alliance som bæ- 
repille for det globale system fra 1941 vil det være katastrofalt at undervurdere betydningen af det begyndende opbrud.

Den virkelige risiko for vores fremtid ligger i tvivl om egen rolle og tabt tro på egen formåen og samfundsmæssige styrke. Vi famler. Det er der mange grunde til.

\section{Nye magter}

Den første er fremkomsten af nye magter som Kina, Indien og Brasilien.

Disse tre lande vejer ikke så tungt, som man ofte hører; men det er herfra den globale vækst og dynamik kommer. Undersøgelser i USA om kinesiske og indiske studenter viser, at mod tidligere 80 pct., der ønskede at blive i USA, er det nu omvendt; begrundelsen er bedre karrieremuligheder hjemme. Der hvor pengene er, kommer også fremtidens forskning, udvikling og innovation.

For mange i Europa og USA er Asien stadig en trussel mod arbejdspladser gennem outsourcing; både i EU og USA tordner kritikken mod de asiatiske lande, navnlig Kina. Det ses ikke, som hvad det er. Et historisk skifte som vi skal forstå og udnytte. Det er ikke et nulsumsspil, hvor det, som den ene part tjener, mistes af den anden.

Vores manglende forståelse bliver sat i relief, hvis blikket kastes på mellemstore lande. Tyrkiet, Mexico, Ar- gentina, Indonesien, Sydafrika for blot at nævne nogle få er med på vognen sammen med giganterne og viser utålmodighed med deres ringe placering - næsten overset - i det globale styresystem.

For EU er det tæt inde på livet med Tyrkiet. Igennem årene har der været talt om dets forestående medlemskab. Det bliver aldrig til noget. Det er ikke EU's afgørelse, uanset hvad der siges; men Tyrkiet er blevet en mellemstor magt uden interesse for et medlemskab med efterhånden ikke mange fordele for landet.

Det kommer EU til at fortryde, eftersom Tyrkiet er på vej til at genetablere Det Osmanniske Imperiums indflydelse i Mellemøsten og til en vis grad Centralasien. Tyrkiet er muligvis også lakmusprøven på, om demokrati, et islamisk parti med flertal i parlamentet og sekularisering kan forenes. Svaret herpå bliver centralt for fremtidens politiske struktur i Mellemøsten, Nordafrika og den arabiske verden.

\section{Det globale styresystem halter}

Den anden grund er det haltende globale styresystem. I den internationale debat fremstilles problemet som manglende indflydelse for de fremstormende lande - ofte med groteske sammenligninger mellem fx Belgiens og Kinas stemmevægt i Den internationale Valutafond (IMF) eller Storbritannien og Frankrig som faste medlemmer af 
FN's Sikkerhedsråd. Og det er selvfølgelig et problem, eftersom det giver indtryk af et system, der ikke opfanger udviklingen i den verden, som det skal 'styre'.

Svagheden er imidlertid en helt anden. FN- systemet plus de tre bærende økonomiske organisationer IMF, Verdensbanken (WB) og Den Internationale Handelsorganisation (WTO) er alle gearet til at fremme den grundlæggende amerikanske økonomiske model. Det betegnes ofte som Washington-koncensus, eftersom det var og er den model og den recept, IMF og tillige WB fremførte over for lande i nød med behov for $\varnothing$ konomisk bistand.

Den blev gjort afhængig af, hvad der så smukt kaldtes økonomiske reformer i retning af frit marked, deregulering $\mathrm{mm}$. helt uanset sociale strukturer med rod i ældgamle kulturer. De adskiller sig fundamentalt fra forholdene i den vestlige verden og reaktionen på økonomiske parametre er derfor anderledes. I flere tilfælde udviklede der sig en social nedsmeltning som fx i Argentina omkring år $2000 \mathrm{og}$ Indonesien efter den asiatiske finansielle krise i 1997-98.

Med sammenbruddet omkring 2007 fik piben en anden lyd. Nu viste det sig, at alle de amerikanske råd og hele grundlaget for Washington-koncensus hvilede på sand. I stedet for en flot økonomisk model tegnede der sig et billede af en flosset finansiel moral sigtende på pro- fit gennem uantastet grådighed kombineret med fiskal uansvarlighed næsten ud over alle grænser. Krisen bragte frem, hvad mange måske havde anet, men få erkendt: at deregulering og 'markedet ved bedst' slet ikke havde fremmet konkurrencen, men i stedet skabt konturerne af en korporativ stat.

Koncentrationen af kapital affødte finansiel magt og indflydelse hos få store institutioner, deraf ordene 'for store til at lade falde'. De tre største amerikanske banker kontrollerede fra omkring 1935 til $1995 \mathrm{ca}$ 10 pct. af alle bankaktiver i USA. I dag er tallet ca 40 pct.. Ud af de 1000 største internationale banker har de tre største over det sidste tiår forøget deres andel fra otte pct. til 16 pct. En nylig schweizisk analyse viser, at 147 virksomheder gennem egen aktivitet og besiddelse af egenkapital i andre virksomheder kontrollerer 40 pct. af omsætningen i globale virkomheder. 80 pct. kontrolleres af 1318 virksomheder.

På den baggrund faldt udtalelser og politiske filosofier om marked og konkurrence til jorden som en vingeskudt fugl. 'Den amerikanske model' har mistet sin tiltræknigskraft og dermed undermineret USA's status som global supermagt.

De vestlige lande bar i mange år systemet og opmuntrede resten af verden ja næsten søgte at påtvinge den modellen, men er nu pludselig ved at få betænkeligheder. Der tales om indgreb over for outsourcing og 
blokering af andre landes investeringer i hjemlige virksomheder. Kort sagt: På et tidspunkt hvor andre end dem selv begynder at få gavn af det globale regelsæt, som Vesten igennem mange år gjorde, funderer de vestlige lande over, om de fortsat skal stå som systemets forsvarere.

\section{Knaphedens tidsalder}

Den tredje grund til at EU famler er skiftet fra 200 år med rigelig forsyning af råvarer hen i mod knaphedens tidsalder. I realiteten indebærer det et skifte for den politiske process og den økonomiske model fra fordeling af 'mere ' til at håndtere byrdefordeling. COP15 var første gang nogensinde verdens politiske ledere samledes for at tage stilling til byrdefordeling, fordeling af knapheder, hvem der skulle betale i stedet for at begejstres over at uddele gaver og fordele til hinanden. Hverken det politiske system eller de økonomiske modeller magtede den opgave. Den industrielle model og den økonomiske markedsliberalisme formet gennem mere end 200 år og stadig karakteriseret af Adam Smiths tese om samfundets velstand som akkumulation af de enkelte individders velstand står for fald.

Det fornemmes i Asien, hvor den store og stigende befolkning plus økonomisk vækst gør knapheden nærværende. Heldigvis for europæerne fornemmes det også i Europa, medens US fortsat kører i rillen af overflødigshedshornet, hvor man blot tager til sig uden at tænke på, om der er mere tilbage.

EU er på vej med ambitiøse planer om indgreb over for forurening og udslip af drivhusgasser samt planer om effektivisering af den konventionelle energiforsyning kombineret med investeringer i vedvarende energi. Det er godt og giver EU en acceptabel platform i det globale billede om formning af nye ideer om den fremtidige $\varnothing$ konomiske model. Den koncentreres nemlig om at drage konsekvenserne af et skifte i de relative faktorpriser, hvor råvarepriserne går op med den uundgåelige følge, at arbejdslønnen går ned vi taler om relative priser. Produktivitet skifter fra at være et spørgsmål om forøget produktion pr. arbejdstime pr. person til at være et spørgsmål, om hvor meget mere output, der kan klemmes ud af en enhed af input af resourcer.

EU har behov for at konceptualisere dette i en generel model. De foreliggende forslag er delforslag dvs. beregnet på enkelte dele af et meget større og mere omfattende kompleks - det er godt, men ikke godt nok. En mere ambitiøs plan med ideer om hvorledes vi skal håndtere knaphed, og hvad det fører med sig af muligheder og begrænsninger for de europæiske lande, trænger sig på.

Nu bliver det omvendt. Det slår igennem på det internationale handelspolitiske billede, hvor det hidti- 
dige overtag for de industrialiserede lande, som kunne - og rent faktisk gjorde det - klemme de råvareproducerende lande, vendes om. Den internationale handelspolitik er bygget op omkring forbud mod importrestriktioner, nedsættelse og afskaffelse af told på import etc. Som det allerede er set igennem de seneste år med nationale restriktioner på eksport af landbrugsvarer og mineraler bliver billedet i fremtiden risiko for restriktioner og afgifter på eksport af råvarer.

Det kan tillige iagttages, hvorledes en stribe lande, herunder Kina og lande i Mellemøsten, begynder at opkøbe landbrugsarealer eller råvareforekomster for at sætte sig på dem, uanset at de formelt set er dele af andre landes territorium. I Afrika foregår denne trafik i stort omfang. Det samme ses i Australien med politisk opmærksomhed og en til tider hidsig debat om, hvorvidt der skal gribes ind eller ej.

\section{Eurokrisen}

Den fjerde grund er eurokrisen, som givetvis kommer til at sætte sit præg på det europæiske samarbejdes fremtid. EU affødte beundring mange steder som følge af indførelse af én fælles valuta. Det blev anset som enestående ikke alene som en økonomisk operation, men ved at fremhæve styrken i den europæiske integration og de europæiske landes tillid til hverandre. Uanset hvorledes krisen udvikler sig, og hvilken udgang der tegner sig, vil EU fortone sig som billede af Europa og erstattes af eurozonen. Udenforstående lande som UK og Danmark vil tabe i prestige og indflydelse. EU bliver i omverdenens optik synonymt med eurozonen.

Den vigtigste ændring kommer af gode grunde til at ske inden for $\mathrm{EU}$ med en omfattende ændring af samarbejdets struktur. Det fører til mere Europa, som det ofte udtrykkes, med trakattekster, der kobler eurolandene sammen gennem reelle fiskale bindinger. Dermed er udskilningsløbet i virkeligheden i gang og måske endda afsluttet. Stort set alt af interesse bliver afgjort af eurozonen, også et stort antal emner, som ikke direkte har noget med den fælles valuta at gøre. Medlemmerne af eurozonen vil mødes uden deltagelse af ikke-medlemmer og i store træk tage stilling til, hvorledes samarbejdet skal udformes og udvikle sig. De reelle beslutninger truffet i dette forum forelægges derefter for EU som helhed til endossering. Eftersom lande uden for euroen står svagt, vil det sjældent være muligt fundamentalt at ændre de allerede trufne reelle beslutninger.

Kernen i dette bliver den fransktyske akse uanset, om man kan lide at høre det eller ej.

Beklagelser og mishagsytringer fremsat af udenforstående lande som UK og Danmark vil blive mødt med to argumenter. For det første: 
"I har selv valgt ikke at deltage i kernen af det europæiske samarbejde. Så kan I ikke komme og kræve samme ret til indflydelse som den gruppe af lande, der bærer samarbejdet gennem den fælles valuta". For det andet: "I havde igennem adskillige tiår chancen for gennem en integrationsvenlig politik at sætte jeres præg på EU. Det gjorde I ikke. I stedet for aktivt at støtte institutionerne, der er de små og svagere landes beskytter, valgte I at være fodslæbende og stille hindringer i vejen for reel magt til institutionerne. $\mathrm{Nu}$ har vi andre truffet det valg at køre videre inden for en anden ramme, og det har I selv været ude om”.

Det grundlæggende valg bliver i langt højere grad end tidligere, at enten er man med, eller også er man det ikke. Lande i EU, men ikke i eurozonen glider langsomt, men sikkert over i tilpasningsrollen, dvs. de former ikke politikken, men deltager i dens gennemførelse, og deres erhvervsliv fungerer med fri adgang til det indre marked og andre fælles aktiviteter - men formet af andre.

Nogle vil føle sig fristet til at klassificere det som fransk-tysk magtbrynde med ordene, at nu kan vi endelig se, hvad de var ude på. Det er forkert. De var i virkeligheden ude på at skabe et andet Europa. Som udenrigsminister Genscher i sin tid formulerede det, stod valget mellem et tysk Europa eller et europæisk Tyskland. Det var Europas ubetinget stærkeste økonomiske magt, Tysk- lands, tilbud til resten af Europa. For Tyskland og Frankrig er et stærkt og levedygtigt europæisk samarbejde med en fælles valuta et spørgsmål om at overleve i den globale konkurrence. Tyskland og til dels også Frankrig er ikke indstillet på at se deres industri og erhvervsliv blive kvalt langsomt som følge af modstand mod integration og benspænd fra andre landes side. Det er driften for at overleve, som tvinger dem frem mod en anden struktur end den nuværende skabelon.

Amerikanske økonomer mener, at alting, som ikke svarer til USA, ikke kan fungerer, og taler om Tysklands fristelse til at forlade euroen. Det er en total misforståelse. Det europæiske valutasamarbejde blev grundlagt i slutningen af 1970'erne af Tyskland og Frankrig, fordi tysk industri klart så, at uden faste valutakurser ville de øvrige europæiske lande gennem devalueringer udmarve den tyske konkurrenceevne. Skulle Tyskland fastholde den tyske stabilitetspolitik med lav inflation og orden i statsfinanserne krævede det, at størsteparten af de europæiske konkurrenter gradvist accepterede en tilsvarende stabilitetspolitik.

Og det er lige præcis, hvad der er sket. Dermed fjernes motiverne for Tysklands udtræden af euro'en. Internationalt betyder det, at eurozonen begynder at fremstå på samme måde, som Tyskland gjorde det i sin tid med D-mark'en, nemlig et område med finansiel ansvarlighed og 
lavinflation. I starten vil det kræve omkostninger og ofre - det bliver ubehageligt. På længere sigt vil det give endog meget store fordele, som udviklingen i Tyskland så klart har vist. Resten af verden kommer til den konklusion, at eurozonen med en økonomisk politik under overskriften 'sætte tæring efter næring' er mere tiltrækkende end den amerikanske økonomiske politik baseret på fortsat gældsfinansiering og store underskud.

\section{UK's aftagende rolle}

Den femte grund er UK's aftagende rolle inden for EU, som rejser spørgsmålet om det i virkeligheden er på vej ud. Skiftende britiske premierministre har på hver deres måde talt om UK i kernen af Europa; men faktum er, at UK altid har spillet en perifer rolle fortrinsvis som bremseklods for fransk-tyske initiativer.

Den militære magtvektor har fastholdt den britiske indflydelse. UK på linje med Frankrig var alene i stand til at projicere magt. Tyskland gled ud af denne ligning, fordi landet dels ikke har en militær kapacitet dels ikke har ønsket at påtage sig en sådan rolle. Med de næsten dramatiske beskæringer i det britiske militær falder dette kort bort efterladende UK som et medlem, der i store træk ikke er interessant - uden for kernområderne og utilpas ved sit medlemskab. I UK er der stigende tilslutning til enten at udnytte en traktatændring ønsket af eurolandene til at svække EU's rolle - i det mindste over for UK - eller direkte udtræden. Flere forhold vil aktualisere dette i 2012.

Eurolandene vil formentligt se forslag til traktatændringer for Eurozonen på bordet. Det er usikkert, men sandsynligt, at dette vil kræve stillingtagen fra også de EU-lande, som ikke deltager i eurozonen.

Standpunktet hos eurolandene vil være, at eftersom det ikke vedrører de udenforstående lande, men afspejler en traktatmæssig formalitet, er disse lande så at sige uden for spillet og bør ratificere en traktatændring af betydning for andre, men ikke for dem. Store kredse i UK vil se anderledes på det $\mathrm{og}$ have svært ved at modstå fristelsen til at bruge eurolandenes behov for en traktatændring til at søge britiske særinteresser herunder reduktion af EU-reglers status i UK ændret.

Premierminister Cameron har tidligere udtalt, omend i ikke helt utvetydige vendinger, at en fremtidig traktatændring skal underkastes folkeafstemning. Det er ikke svært at se det politiske problem, der tårner sig op, hvis en folkeafstemning i UK om ændring af traktaten, som ikke vedrører dette land, forkastes med den konsekvens, at eurolandene ikke kan tilpasse deres samarbejde, som de ønsker. Måske kan traktatændringer formuleres således, at kun eurolandene skal ratificere, og måske kan premierminister Cameron smy- 
ge sig udenom; men det er langt fra sikkert, at brikkerne falder på den måde.

Den 27. oktober 2011 gennemtvang modtandere af EU inden for det konservative regeringsparti en vejledende afstemning i Underhuset om afholdelse af en folkeafstemning om ja eller nej til EU. Forslaget blev forkastet med stort flertal, men ud af 315 konservative stemte 79 for dvs. imod regeringen uanset hårdt pres fra premierministeren. En opininionsundersøgelse stort set samtidig fortæller, at 49 pct. af briterne $\varnothing n s k e r$ at træde ud af EU med 41 pct. for fortsat medlemsskab. På den baggrund er premierministerens manøvrerum ikke stort. Billedet kompliceres af et parallelt forløb om folkeafstemning i Skotland for at træde ud af UK. Der tegner sig således et muligt billede af Skotland, der træder ud af UK, England forlader EU, og Skotland forbliver.

Oven i dette kommer EUs flerårige finansielle rammer, som udløber i 2013 og derfor skal genforhandles i 2012. Et af de mest sårbare punkter er den britiske budgetrabat med rødder tilbage til 1980 under premierminister Thatcher og forlænget med modifikationer siden da, sidste gang i 2005. Daværende premierminister Tony Blair firede på størrelsesordenen med 20 pct. svarende til ca 10 milliarder Euro over syv år. Han sad i formandssædet, hvilket givervis forklarer en del af den britiske smidighed. I stedet for en europavenlig premierminister fra labor med et tvetydigt forhold til premierminister Thatchers europapolitik kommer i 2012 en britisk premierminister med et stærkt skeptisk for ikke at sige negativt bagland, hvis synspunkter han i det mindste delvis deler. Uanset resultatet af forhandlingerne er det givet, at det uddyber kløften mellem UK og størsteparten af de øvrige lande.

Disse fem elementer tegner billedet af et og sikkert flere turbulente år for EU med dybtgående ændringer. Det mest sandsynlige er, at 2012 ser begyndelsen hen i mod et EU koncentreret omkring en kerne af lande rodfæstet i Eurozonen, resten af medlemslandene i mere eller mindre løst forhold hertil og et stort spørgsmålstegn omkring UK's fortsatte placering i eller endog medlemskab af EU.

Det vil tage et par år at afklare dette, og først derefter vil EU kunne spille en reel rolle i udformningen af en ny verdensorden, der præges af dybtgående ændringer i kølvandet på aftagende amerikansk magt og skifte til emner som global opvarmning, knaphed på råvarer $\mathrm{og} \mathrm{de}$ fremstormende landes krav om mere magt og indflydelse inden for det globale styresystem.

Jørgen Ørstrøm Møller, forsker ved Institute of Southeast Asian Studies, Singapore; adjungeret professor Copenhagen Business School; fhv. departementschef $i$ Udenrigsministeriet. 